5. Striuk, А.: Проектирование учебных объектов дополненной реальности [Electronic resource] / Андрей Стрюк // Transactions. Georgian Technical University. Automated control systems. - 2018. - № 2(26). - C. 127-134. - Access mode : https://gtu.ge/Journals/mas/Referat/N26_conf_unesco_2018_2_26.pdf

6. Аванесов В. С. Основы теории педагогических измерений / В. С. Аванесов // Педагогические измерения. 2004. - № 1. - C. 15-21.

7. Бондаренко М. Ф. Оценивание тестовых заданий разных типов и определение их уровня сложности / М.Ф. Бондаренко, В. В. Семенец, Н. В. Белоус, И. В. Куцевич, И. А. Белоус // Штучний інтелект. - 2009. - № 4. С. 322-329. - Бібліогр.: 7 назв. - poc.2 . http://www.foibg.com/ibs_isc/ibs-12/ibs-12-p07.pdf

8. Кольцов Ю. В. Нейросетевые модели в адаптивном компьютерном обучении / Кольцов Ю. В., Н. Ю. Добровольская // Educational Technology \& Society 5(2), 2002. - С. 213-216.

9. Wulansari Y. The Use of Visual Auditory Kinesthetic (VAK) Learning Model to Improve Students' Reading Comprehension: Graduating Paper // Yeni Wulansari. - Salatiga : State Institute for Islamic Studies, 2016. - 178 p.

10. Фетискин Н. П. Диагностика доминирующей перцептивной модальности (С. Ефремцева) / Н. П. Фетискин, В. В. Козлов, Г. М. Мануйлов. Социально-психологическая диагностика развития личности и малых групп. - М., 2002. - С.237-238. - Режим доступу до pecypcy: https://psycabi.net/testy/289-test-audial-vizualkinestetik-diagnostika-dominiruyushchej-pertseptivnoj-modalnosti-s-efremtseva

11. Грегос А. Р. Методика «Реестр стиля информационного усвоения» [Електронний ресурс] / А. Р. Грегос. Режим доступу до ресурсу: https://psytests.org/cognitive/gregos.html

12. Челомбітько В. Ф. Використання ілюстративного матеріалу для створення книжкових та електронних мультимедійних видань / В. Ф. Челомбітько, М. О. Мажуга // Бионика интеллекта. - 2016. - №1 (86). - С. 112-115.

13. ГОСТ: Организация данных в системах обработки данных. Термины и определения. ГОСТ 20886-85.

14. Шаповалова Н. Н. Порівняльний аналіз методів оптимізації функціоналу якості моделей машинного навчання / Н. Н. Шаповалова, О. Г. Рибальченко, Д. І. Куропятник // Вісник Криворізького національного університету : зб. наук. праць / національний університет Криворізький ; М-во освіти і науки України, ДВНЗ «КНУ».Кривий Ріг, 2018. - Вип. 46. - С. $104-112$. $260 \mathrm{c}$.

15. Saternos C. Client-Server Web Apps with JavaScript and Java / Casimir Saternos. - USA: O'Reilly Media, 2014. -

Рукопис подано до редакції 05.10.2020

УДК 629.1.072.2

I.V. HIRIN, Senior Lecturer, V.Yu TYSHCHENKO, Research Associate, Kryvyi Rih National University

\title{
COMPARATIVE ANALYSIS OF SAFETY DESIGN FOR ELECTRIC VEHICLE AND INTERNAL COMBUSTION ENGINE CARS
}

Purpose. A comprehensive study of the current safety design of electric vehicles (EVs), identifying the problems to be addressed for the development of the national electric mobility market infrastructure and the competition with conventional internal combustion engine cars (ICE) in Ukraine.

Research methods. Synthesis and analysis of the published theoretical developments using world statistical indicators on electric vehicles, analytical calculations, and statistical analysis. The methodology of theoretical research is based on the logical and mathematical methods. A number of particular methods are as follows: axiomatic and hypothetical methods, analysis and synthesis, interpretation method. An integrated approach including synthesis and analysis of literature review and research on automobile transport.

Scientific novelty. The analytical assessment of the safety design of up-to-date electric vehicles and the identification of the key directions and technical capabilities to further enforce of active, passive, post-accident and environmental safety of electric vehicles.

Practical significance. The main design criteria result in reduced road traffic fatality rates thanks to a number of electric vehicles on the road. The high dependence of the whole EV safety design on individual parts and units of the EVs has a direct impact on improving road safety.

Results. A comparative analysis of the technological components of active, passive, post-accident and environmental safety of electric vehicles and conventional cars. Test results of EVs compared to ICE cars are summarized. An assessment of fire risks of vehicles equipped with electric batteries of different types. The constructive solutions of modern mass-produced electric vehicles, which pose the greatest threat to road safety, are noted. Further research priorities for improvement of electric vehicle safety design are identified.

Key words: electric vehicle, safety design, electric vehicle battery, crash tests of electric vehicles.

doi:10.31721/2306-5451-2020-1-51-57-62

Problem statement. Although the popularity of the electric cars are growing at an incredible rate in the modern world of high technology every year, their development has problems and controversial issues. It is obvious that an electric vehicle (EV) and a conventional internal combustion engine (ICE)

(C) Hirin I.V., Tyshchenko V.Yu., 2020 
vehicle cannot yet be compared. However, the electromobile industry is strongly supported. In some countries, the Government gives tax reliefs to EV users like tax free parking and permission to drive into city "no-go areas". Other countries encourage car manufacturers to reduce vehicular emissions. Big car manufacturers and technology companies supported by state plan to expand and improve their products.

The electromobile industry is rapidly commercializing even without stimulation factors. In 2018, electric cars and hybrids were sold up 791130 units more than in 2017, thus sales growth amounted to 64\%. According to Insideevs.com, more than 2 million units of new Plug-In Hybrid Electric Vehicles (PHEV) were sold worldwide in 2018.

In view of the current energy carriers, the State government is primarily interested in a wide range of e-mobility application resulting in energy independence, higher environmental well-being and economic benefit of Ukraine. Electric cars would benefit both the state authorities and users.

Analysis of the recent research and publications. The efficient and safe use of road transport, the influence of usage conditions on the technical and operational performance of motor vehicles and the problem of road safety are reflected in the works Avdonkin F.N., Arinin A.N., Afanasiev J.L., Babkov V.F., Bezborodko M.B., Boldin A.P., Velikanov D.L., Vlasov V.M., Ginzburg L.L., Govoruschenko H., Zyrianov V.V., Ivanov A.M., Ilarionov V.A., Indikt E.A., Karagodin V.I., Klinkovstein G.L., Knoroz V.A., Konoplyanko V.I., Korchagin V.A., Kramarenko T.V.., Kuznetsov E.S., Lakhno R.P., Litvinov A.S., Lukanin V.N., Maksimov V.A., Mirotin L.B., Miroshnikov L.B., Moroz S.M., Narbut A .N., Nefedov A.F., Ostrovtsev A.N., Platonov V.F., Reznik L.G., Rotenberg R.V., Ryabchinsky A.I., Silyanov V.V., Tokarev A.A., Tolsky V.E., Trofimenko Y.V., Farabin E.E., Khachaturov A.A., Chudakov E.A., Sheinin A.M., Yurkovsky I.M., Yurchevsky A.A., James Migletz, Thomas Hedblom, Ludwig Eigenmann, etc..

The comprehensive and in-depth academic studies on road safety of electric cars are mostly underrepresented. Moreover, recommendations on how to ensure real safety of electric vehicles are not formulated in most works. An analysis of the earlier published papers and regulatory documents (national and foreign) showed that they provide only recommendations on improving individual units and systems of the EVs and cannot be used as a quantitative technical and economic impact of electric vehicle design safety on crashes.

Objectives of the article. Ukraine has put forwards significant developing the e-mobility. Marketing agency IRS Group has published the latest statistics of the electromobile market in Ukraine for May 2019, whose EV sales reached 1419 items, which is $31 \%$ more than a month before. Processing the May figures, the number of electric motor vehicles to date reaches 25 175, of which 13 $287 \mathrm{EVs}$ and 11884 hybrids of all modifications. Nissan Leaf holds the leading positions in the Ukrainian market. However, according to May statistics BMW i3 $(+1 \%)$ and Toyota RAV $4(+1 \%)$ sales also increased. The development of electricity infrastructure and the abolition of import duties enabled electric vehicles to become cheaper at an average rate of $10 \%$. Most electric vehicles are purchased in Kyiv and regional cities around the Ukraine.

The importance of new generation of electric vehicles naturally raises concerns over safety on roads. Accordingly, the following research objectives were formulated:

to review and analyze the safety design of EVs and explore a sustainable trend towards higher highway safety levels;

to review and systematize the design concepts of structural systems, units and spare components of EVs, which radically increase road safety;

to develop methods for the safe integration of EVs in the smart transport environment.

Presentation of the main research and results. There are five ambiguous statements concerning the safety of electric vehicle.

1. The safety design of electric vehicle is low.

For several years, electric cars and gasoline cars have been passed the similar crash tests EuroNCAP tests in Europe and IIHS test in the US. The EVs like ICEs differ in results. Their general safety design is high, the airbags deploy during a crash, the crash sensors disconnect the batteries and stop the car. The airbags are intended to reduce serious injuries of a driver and occupants of the electric vehicle, as well as the occupants of the other collided vehicle.

For example, the results of the North American electric vehicle crash test in 2011 are given bellow. The Chevrolet Volt and Nissan Leaf earned a five-star rating in safety during frontal and side 
crashes when hitting behind, and during a crash simulation when a car overturns. The Insurance Institute for Highway Safety (IIHS) tested two electric vehicles, BMW i3 and Tesla Model S. Both models performed well, although they did not get the highest rating of Top Safety Pick +. In order to get the highest rating, it is necessary to show superior results in all tests. The electric car BMW i3 was rated Good almost in all crash tests. However, its head rests were rated Acceptable. IIHS experts praise the preventive braking system of the BMW i3.

The Tesla Model S electric car also achieved Good in most tests. However, a seat belt did not properly protect the driver dummy's head from hitting the steering wheel hard through the airbag in small overlap frontal crashes.

It should be noted that the design of the electric car makes it more secure in case of a collision. Liion battery is located within the wheelbase under the bottom of the car. Thus, compared to a gasoline car, the center of gravity of the EV is placed lower. Consequently, it is much more difficult for the EV to turn over in an accidental collision.

As the EV is not equipped with a large fuel tank, the Tesla Motors experts offer to make longer deformation zones to absorb high-speed shock energy.

2. Traction Inverter for electric and hybrid vehicles can be very quiet at low speed, making them difficult for pedestrians to detect, that causes a car-pedestrian crash.

In fact, this problem could be greatly eased through the following technical solutions. The National Highway Traffic Safety Administration (NHTSA) of the United States has adopted a new standard for electric and hybrid vehicles. Since September 2019, existing electric or hybrid vehicles are gradually to be retrofitted with sound devices to indicate their presence on roads for the blind and partially sighted people. According to the new standard, all EVs/HEVs with a full weight of up to 4.5 tons (excluding passenger and cargo weight) have to be sounded. The acoustic signal is to be activated if such a vehicle reverses or moves forward at a speed less than $30 \mathrm{~km}$ per hour. According to NHTSA, at speeds above $30 \mathrm{~km}$ per hour, an acoustic signal giving blind pedestrians information about the presence of a nearby quiet car is not required. The fact is that a fast-moving EV with no special signal makes enough noise to be heard. It is about tire noise and aerodynamic noise.

3. Electric vehicle battery has an increased risk of fire.

Manufacturers have been paying considerable attention to this risk ever since the crashed Chevrolet Volt in the United States in 2011. This is due to the fluid leaking from the battery cooling circuit. However, the National Highway Traffic Safety Commission (NHTSA) later concluded that the Volt model does not have a general tendency for manifest defects, and recent General Motors improvements minimize the risk of fire in the event of side collisions.

Lately, there were two incidents when Tesla cars broke out twice due to a collision with metal debris on the road. Tesla Model S, manufactured since 2012, currently they are about 107,000 cars on the road. In fact, 6 fires occurred resulted from:

10.01.2013 - a bottom hole with metal debris,

10.18.2013 - accident in Mexico,

11.06.2013 - bottom hole with metal debris,

11.15.2013 - a battery charge;

02.11.2014 - a car caught fire in a parking lot in Toronto (the reason was never announced);

01.01.2016 - a case of ignition of an electric car at a fast recharging station in Norway;

And now let us compare Tesla EV with ICE:

There were 6 fires for 107000 Tesla Model S and 2600 Tesla Roadster, which is $0.0055 \%$.

In 2013, this would mean 27,000 cars and $0.014 \%$.

The data on the ICE vehicles are as follows: - Between 2006 and 2010, on average 152300 vehicle fires occurred every year. At present, there are 250 million vehicles in the United States, which amounts $0.061 \%$ of fires every year.

There are also the following statistics. In the US, there were about 219 thousand fires per 254 million vehicles in 2011, which was about $0.085 \%$.

Between 2003-2007, the situation got even worse: 287 thousand fires per approximately 240 million vehicles, which was about $0.12 \%$. Thus $49 \%$ of them were caused by vehicle breakdowns, $23 \%$ by electrical problems, $8 \%$ - by deliberate action, $3 \%$ - by road accidents, and $5 \%$ - by other sources of fire. 
There is a big difference in above-mentioned Tesla performances in a favour the latter. It should be noted that the ignition statistics are given without taking into account the age of the machine. Since Tesla is not yet 9 years old, it is not quite correct to compare these values. The average age of a vehicle in the US is 11.5, and fires are calculated for all vehicles.

After the two incidents of Tesla cars' fire due to a collision with metal debris, the company provided the titanium-aluminum plates on all Model $\mathrm{S}$ to protect the bottom, and at customer requests modified the bottom of the cars already sold.

Thus, we may conclude that ICEs currently have a far higher percentage of auto-ignition than EVs. In addition, the explosion presents an immediate and more significant danger than a flame, hence, the very dangerous automobile is powered by liquefied gas.

4. Electromagnetic radiation exposure to occupants of the vehicles.

Numerous studies conducted by world-leading companies and experts have measured the electromagnetic fields (EMFs) and exposure levels to occupants of the vehicles. Particular attention was paid to the potential risk of cancer, miscarriage and child leukemia. Given the fact that batteries are most often located directly under the driver and passengers, this means that long-term EMF effects are inevitable. The maximum value of this parameter was fixed at the start of the car engine, and the point closest to the pallet where the power source was installed became the limit value. However, even in this case, the registered maximum of the magnetic field was below the limits recommended by the International Commission on Nonionizing Radiation Protection (ICNIRP). Despite the study results, many users of hybrid or electric vehicles are more concerned about the symptoms such as headache, anxiety, suicide and depression, nausea, fatigue and loss of libido, sleep disturbance and concentration caused by the EMF within a vehicle.

The complex of studies, completed by the Norwegian company SINTEF, reported that such fears are completely unfounded, and the fact of a potential risk was raised by mistake or intentionally.

During the road test, seven models of EVs powered by different systems were involved. Hybrid models, equipped with electric, gasoline (diesel) and hydrogen engines, have passed both the laboratory and road testing. Sensors in the dummy on the head, chest and legs showed that the fixed value of EMF at these points is $2 \%$ of the normalized recommended value for humans. The findings of a series of studies in six other countries also confirm, that electric cars are absolutely safe for human health, and the magnetic field value created by electrical equipment is less than the recommended value.

5. Electric vehicle batteries are toxic.

To date, the three batteries most commonly used in the road transport industry are as follows: lead-acid batteries, lithium-ion batteries, and supercapacitors. It is obvious that a lithium-ion battery represents a decisive competitive advantage in terms of energy / mass ratio. The theoretical voltage limit of a modern 18650 block is $4.2 \mathrm{~V}$, but no battery allows it to be used. When the safe level is lowered, the Lithium plating occurs. Thus, the formation of conductive sections of lithium leads to an internal short circuit and, as a consequence, thermal runaway, (Fig. 1).

This situation is possible when exposed to lower temperatures. When the voltage is exceeded, a

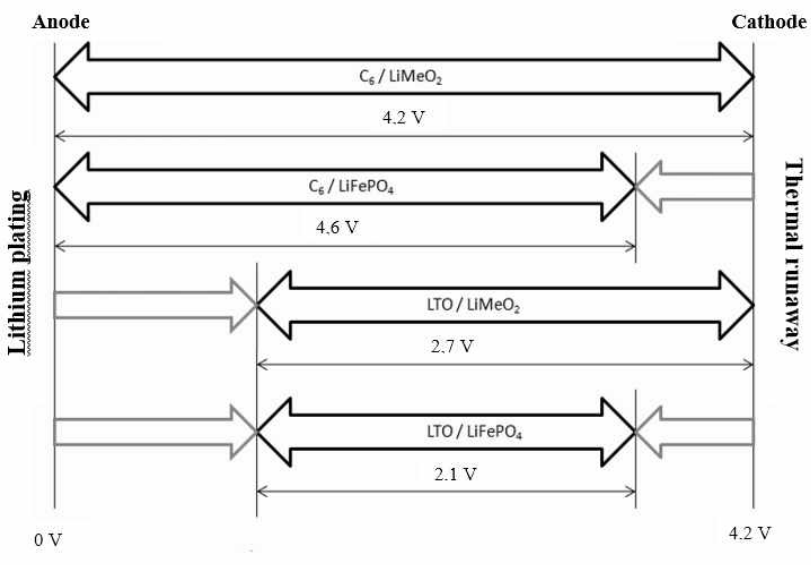

Fig. 1. Lithium plating in various types of batteries (the type of battery indicates the voltage when fully charged) temperature instability of the cell also leads to its destruction. Thus, there is a need to limit the voltages on the top and bottom because of some variation in the performance production. In this regard batteries with a voltage of $2.1 \mathrm{~V}$ with LTO and LiFePO4 electrodes are considered to be the most secure, however security is ensured by reducing the voltage, and therefore paying for energy about twice. In modern lithiumion batteries, the anode is usually a layer of graphite deposited on a copper foil. During the charge, lithium ions accumulate in the graphite layer. This design was devised for reasons of safety 
and durability - the anode of pure lithium metal degrades very quickly, as the charge gradually grows "branches" on its surface, which, reaching the cathode, can cause a short circuit. The use of graphite "sponge" solves this problem, but the energy intensity of graphite anode is about 350 milliamp-hours per gram, while in pure lithium this figure is 11 times higher. A team of Stanford University scientists led by Professor Yi Cui have developed a technology that prevents the formation of lithium "branches" on metal lithium anode and paves the way for reliable, much more capacious batteries. In practice, it can be a three or four-fold increase in capacity.

Currently there is no alternative to lithium-ion batteries (LIBs) for electric vehicles. It is understandable that electric vehicle LIBs must be disposed, while lead-acid batteries for petrol cars are potentially unsafe and environmentally undesirable. In addition, the demand for lithium as the most valuable component of LIBs is now growing rapidly, and the mining industry is not keeping up with this demand. Thus, LIB recycling when these vehicles reach the end of their lives is very important. Additionally, end-of-life LIBs can be used in second-use applications as balancing power in electrical networks, moreover enhance environmental benefits.

It should be added that the European Union is developing common requirements for the safety design of electric vehicles and their use in the Old World. The requirements document all the possible risks associated with the use of electric vehicles and ways to prevent them. In particular, the future regulation should protect drivers and passengers from electric shocks and take into account the impact of noiseless electric vehicles on road traffic safety. According to the European Union statement, 27 EU governments have to protect the EU's 500 million population with the document. The safety design requirements for electric vehicles are expected to be completed within two years.

Conclusions. Despite the shortcomings of EVs, it should be noted that the safety design of EVs is competitive with ICEs and even exceeds in some components. EV constitutes a silent menace to individuals with sight loss due to travelling at low speeds. One of the possible ways to tackle electric cars' silent menace to pedestrians is to equip existing vehicles with sound emitters. Sound device would be used when driving in urban areas with lower limits and automatically based on the movement of the vehicle, and when reversing.

\section{References}

1. Лебедева А. С. К вопросу об экологической безопасности на автомобильном транспорте // Лебедева А. С., Табачникова Е. В // - Научное обозрение: теория и практика. - 2014. - № 3. - С. 41-45.

2. Щетина В.А. Электромобиль: техника и экономика. / Щетина В.А., Морговский Ю.Я., Центер Б.И., Богомазов В.А /- Л: Машиностроение, 1987. — 253 с.

3. Жук А.З. Электромобиль на алюминиевом топливе. // -Жук А.З., Клейменов Б.В., Фортов В.Е., Шейндлин А.E. //- М: Наука, 2012. - 171 c.

4. Форсаж 7 [Электронный ресурс]: многопредмет. авто. журн. / Киев. - Электрон. журн. - 2016. - Режим доступа: http://zhurnul.milt.rissi.ruhttp://forsage7.com.ua/blog/plusi-i-minusi-elektromobiley/

5. Эйдинов А.А. Расчетные исследования возможностей тяговых источников тока для электромобилей.-/ Эйдинов А.А., Дижур М.М. // -М.: Труды МАМИ, 1996. -138 с.

6. Германия раздает бонусы на электромобили. - Сайт, посвященный новостям в сфере высоких технологий, а также инноваций в мире интернета, автопромышленности. [Электронный ресурс]. Режим доступа: http://innotechnews.com/innovations/910-germaniya-razdaet-bonusy-na-elektromobili

7. Шуркалов П.С. Инфраструктура зарядных станций для электрических транспортных средств на основе возобновляемых источников энергии / Шуркалов П.С. // Возобновляемые источники энергии: материалы восьмой научной молодежной школы с международным участием - М.: Университетская книга, 2012, с. 465-469

8. Скундин А.М. Современное состояние и перспективы развития исследований литиевых аккумуляторов / А.М. Скундин, О.Н. Ефимов, О.В. Ярмоленко // Успехи химии. - 2002 - №71 (4) С.378.

9. Bolun Xu. Modeling of Lithium-Ion Battery Degradation for Cell Life Assessment/ Bolun Xu. //Article in IEEE Transactions on Smart Grid June 2016

9. G. Ning R. E. White, and B. N. Popov, "A generalized cycle life model of rechargeable li-ion batteries," Electrochimica Acta, vol. 51, no. 10, pp. 2012-2022, 2006.

10. Topolsky D.V. Modelling of components of hybrid and city transportation in shareware soft / D.V. Topolsky, E.V. Solomin, I.G.Topolskaya,N.D. Topolsky // Journal of computational and engineering mathematics, 2015.- T. 2, № 3- c. 3-12.

11. Дубасова В.С. Исследования и производство материалов для литийионных аккумуляторов в России и за рубежом / В.С.Дубасова, Л.С., Каневский // Электрохимическая энергетика. 2005. Т.5. - №2. - С.109-119.

12. Каневский Л.С. Деградация литий-ионного аккумулятора и методы борьбы с ней/ Л.С. Каневский В.С.Дубасова // Электрохимия. - 2005. - том 41. №1, с.3-19.

13. P Gorny Monitoring and Health prognosis of Lithium-Ion battery system // Piotr Gorny, Piotr Morz, Tadeusz UHL // 8th European Workshop On Structural Health Monitoring (EWSHM 2016), 5-8 July 2016,

14. Сидоров К.М. Энергетическая и топливная эффективность автомобилей с гибридной силовой установкой. дисс. на соискание канд.техн.наук. Специальность: 05.09.03 - Электротехнические комплексы и системы. М. -2010. 
15. Черных И. В. Моделирование электротехнических устройств в MATLAB, SimPowerSystems и Simulink / И. В. Черных. // - М.: ДМК Пресс; СПб.: Питер, 2008. - 288 с.

16. Копылов И.П. Математическое моделирование электрических машин / И.П. Копылов // - М.: Высш. шк., 2001. $-327 \mathrm{c}$.

17. Ютт В.Е. Результаты стендовых испытаний унифицированного электромеханического узла трансмиссии транспортного средства с индивидуальным приводом ведущих колес / В.Е. Ютт, К.М. Сидоров, Д.Б. Лазарев // Современные проблемы науки и образования. - 2014. - №1. - С.201

18. Сидоров К.М. Перспективные системы тягового электрооборудования для транспортных средств/К.М. Сидоров, Т.В. Голубчик, В.Е. Ютт//Вестник МАДИ. -2012. -№ 1 (28).

19. Шрейнер Р.Т. Координатная стратегия управления непосредственными преобразователями частоты с ШИМ для электроприводов переменного тока / Р.Т. Шрейнер, В.К. Кривовяз, А.И. Калыгин // Электротехника. 2003. - №6. - C. 39- 47

20. Sergey A. Serikov. Synthesis of Optimal Control of Hybrid Engine Unit. // Journal of Automation and Information Sciences. Begell House, Inc. (USA) '2009, volume 41, issue 3. - Pages 71-81

21. Карпов В.В. Разработка методов оценки безопасности маневра автомобиля: дис. канд. техн. наук. 05.22.10,05.05.03. - M.2005. $180 \mathrm{c}$.

22. Русаков В.3. Безопасность автотранспортных средств в эксплуатации: дис. докт. техн. наук.05.22.10. M.2004. $360 \mathrm{c}$.

23. Ахмедов А.А. Улучшение управляемости и устойчивости автомобиля при движении по неровной дороге методами многокритериальной параметрической оптимизации: дис. канд. техн. наук.05.05.03. - М.2004. - 169 с.

24. Ходес И.В. Компьютерная поддержка активной безопасности водителя / Ходес И.В., Бондаренко М.В. // Автомобильная промышленность. 2008. №7. С.20-23.

The editorial board received a manuscript on 01.10 .2020

\section{УДК 65.012.122}

І.В. ЗАВССГДАШНЯ, канд. екон. наук., доц., С.Л. ЦВІРКУН, канд. техн. наук, ст. викл., П.В. БУРНАСОВ, ст. викЛ., О.Ю. СЕРДЮК, О.О. ЗАВСЄГДАШНЯ, асистенТи Криворізький національний університет

\section{ОПТИМІЗАЦІЙНЕ МОДЕЛЮВАННЯ РОЗПОДІЛУ ПРОДУКЦЇ̈ ВИДОБУВНОГО ПІДПРИЕМСТВА МІЖ КОНТРАГЕНТАМИ}

Мета роботи полягає у розробці оптимізаційної економіко-математичної моделі для планування збуту продукції видобувного підприємства, яка б враховувала не тільки значення цільової функції - умову максимізації обсягів збуту та доходу від основної діяльності, але також враховувала пріоритетність (рівень значимості) контрагентів для добувного підприємства.

Методи дослідження: у роботі використовувався метод теоретичного аналізу в процесі дослідження науковопрактичних розробок та підходів до моделювання розподілу продукції виробничих підприємств між споживачами; системний аналіз використовувався для розробки структурно-логічної схеми, що відображає етапи підготовки до прийняття рішення щодо оптимального планування збуту продукції а також формування методики ранжування контрагентів; методи економіко-математичного моделювання використовувались для розробки оптимізаційної моделі розподілу продукції; статистичні методи використовувались для розрахунку фактичного значення параметрів моделі.

Наукова новизна: полягає у тому, що запропонована економіко-математична модель, застосування якої забезпечує оптимізацію процесу розподілу продукції підприємства, враховує рейтинг контрагентів а також ситуативний характер процесу розподілу продукції.

Практична значимість. Робота присвячена розробці оптимізаційної моделі для обгрунтування прийняття рішень при розподілі продукції між контрагентами, в ситуації, коли відбувся недостатній видобуток корисної сировини. Проблемою $\epsilon$ прийняття рішення щодо того, хто з контрагентів $\epsilon$ більш пріоритетним. В даній роботі запропоновано застосовувати методи експертної оцінки контрагентів продукції, та ранжування їх. Дана модель є релевантною для підприємств, що виробляють однотипну продукцію.

Результати. В результаті роботи було досліджено теоретичні основи планування збуту та розподілу продукції добувного підприємства; сформульовано рекомендації щодо побудови рейтингу контрагентів продукції підприємства; розроблено оптимізаційну модель планування збуту продукції добувного підприємства за різних умов виконання планового обсягу добутку корисних копалин. Розроблену модель було застосовано для умов видобувного підприємства для різних варіантів недовиконання та перевиконання планових показників виробництва. Модель складено на основі базової відкритої інформації за 2017 р. Враховано умову щоквартального планування поставок.

Ключові слова: оптимізаційна економіко-математична модель, експертне оцінювання, збут, недовипуск, гірничо-видобувне підприємство.

doi: 10.31721/2306-5451-2020-1-51-62-69

() Завсєгдашня І.В., Цвіркун С.Л., Бурнасов П.В. , Сердюк О.Ю., Завсєгдашня О.О., 2020 